\title{
Analisis Penayangan Film Kartun Anak-Anak di Televisi Swasta Nasional Indonesia dalam Memberikan Pesan Moral pada Anak-Anak
}

\author{
Elisabeth Nugrahaeni
}

\begin{abstract}
This study describes the analysis of a cartoon showing children in national private television in providing moral knowledge. The research was conducted in three private television is RCTI, MNCTV, and SpacetoonTV. The research looked at the moral messages given through these cartoons. Most of television is already presenting cartoon movies that give a moral message. However, the results of this study indicate that Indonesia has not been presented on national television films in the country that gives a moral message in accordance with national culture.
\end{abstract}

Keywords: communication education, cartoon kids, the moral message

\section{Pendahuluan}

Anak-anak merupakan aset bangsa yang berguna bagi pembangunan bangsa dan negara. Sudah sepantasnya anak-anak memperoleh informasi yang bermanfaat bagi pengembangan dirinya menjadi seseorang yang berguna bagi bangsa dan negaranya. Sebagai modal dasar keberhasilan seseorang menjadi pribadi yang mandiri dan berdaya guna bagi lingkungannya, maka perlu bagi seseorang sejak masih kecil dibekali pengetahuan untuk perkembangan kognitifnya dan nilai-nilai moral yang baik bagi pengembangan pribadinya.

Proses pembentukan nilai-nilai positif pada anak-anak sangat dipengaruhi oleh apa yang menjadi stimulus di dalam dirinya. Pendampingan keluarga juga tidak bisa dilakukan selama 24 jam untuk anak-anak, karena adanya lingkungan dan media massa. Dengan kerasnya arus informasi melalui media massa penanaman nilai-nilai kognitif tidak hanya dilakukan oleh keluarga dan guru saja.. Salah satu kondisi lingkungan yang mempengaruhi masyarakat adalah media massa. Media massa baik cetak maupun elektronik sangat berpengaruh. Hiburan dan informasi yang paling mudah diperoleh adalah melalui media massa. Selain ringkas biasanya media massa memberikan tayangan yang menarik. Media massa elektronik yaitu televisi merupakan media massa yang paling murah dan bisa memberikan pengaruh positif maupun negatif. Khususnya pesawat televisi. 
Pesawat televisi adalah sebuah benda mati yang hampir tidak memiliki pengaruh apa-apa tanpa sentuhan tangan manusia, Namun, benda ini kini menjadi sebuah perdebatan panjang dalam berbagai diskusi, seminar, analisis, yang tidak ada habisnya. Benda ini menjadi popular karena kesanggupannya menerima siaran dari pemancar yang membawa informasi audio dan visual. Kehadirannya merupakan sarana hiburan, informasi, bahakan pendidikan. Namun tidak sedikit yang melihat keberadaan hiburan di televisi semakin hari semakin memberikan dampak negatif bagi anak-anak.

Namun tidak bisa disangkal dampak lain yang muncul akibat tayangan televisi yang kini terus menonjolkan kekerasan, eksploitasi seksual, horor, maupun mistik untuk sebuah alasan meraup iklan. Banyak kritikan dan kecaman yang ditujukan oleh berbagai kalangan seakan tidak pernah menyurutkan tekad pengelola TV maupun produsen acara TV tetap menyajikan tayangan yang tidak edukatif. Sebagai salah satu pengguna televisi yang aktif adalah anak-anak. Khususnya anak-anak usia 4 hingga 10 tahun.

Berdasarkan artikel di Kompas yang berjudul Anak yang Ketagihan Nonton TV/hal 20/kol 1-9/hari Selasa, 16 Juli 2002 yang menyebutkan sebuah survey yang dilakukan Yayasan Kesejahteraan Anak Indonesia di Jakarta Timur menunjukkan anak-anak menghabiskan waktunya rata-rata 30-35 jam seminggu di depan pesawat TV. Ini artinya, anak-anak sangat menikmati acara televisi, hal ini bisa sangat mempengaruhinya, bahkan pengaruhnya lebih besar daripada didikan sekolah dan didikan orang tuanya. Kenyataan ini tidak melanda hanya anak laki-laki saja tetapi juga anak perempuan yang tidak dipenuhi dengan pengetahuan kekerasan tetapi dengan kemewahan penampilan. Penggambaran bahwa seorang anak laki-laki adalah pribadi yang keras, suka tantangan dan berani untuk bertanding secara perorangan. Dan penggambaran persepsi perempuan sebagai pribadi yang lemah lembut, kurus, langsing, putih, bergaun mewah dan akan segera dijemput oleh pangeran merupakan penggambaran dari film-film kartun untuk anak-anak pada masa ini.

Penggambaran dan penokohan yang demikian sangat membentuk frame of reference dan field of experience seorang anak terhadap nilai-nilai seorang laki-laki dan 
perempuan seutuhnya. Padahal diusia mereka yang masih balita hingga menjelang remaja proses pemaknaan mengenai seseorang sangat berperan penting bagi pengetahuan dirinya.

Berdasarkan hal ini maka penelitian membahas mengenai penayangan film kartun anak-anak di Televisi Nasional Indonesia dalam Memberikan Pengetahuan Moral pada Anak-Anak.

Identifikasi Masalah dalam Penelitian ini :

1. Berapakanh jumlah film-film kartun di televisi yang memberikan pesanpesan moral yang bermanfaat dan mudah dimengerti anak-anak ?

2. Apakah film-film kartun memberikan pesan-pesan moral ?

3. Apakah anak-anak sering meniru tayangan yang terdapat dalam film kartun tersebut?

Pembatasan masalah dalam penelitian ini adalah analisis mengenai pengetahuan moral yang terdapat dari film-film kartun. Pengetahuan moral meliputi nilai-nilai sopan santun, kejujuran, dan sikap tolong menolong. Penelitian ini akan melihat tayangan film yang terdapat di RCTI, MNCTV, dan SpacetoonTV. Penelitian ini dilakukan selama 2 bulan mulai dari bulan September-Oktober 2010

\section{Komunikasi dalam Dunia Pendidikan}

Pendidikan merupakan suatu hal yang mutlak diperlukan bagi setiap manusia. Sejak lahir setiap manusia telah memperoleh pendidikan yang membantu bagi perkembangan dirinya. Setipa tahapan dalam perkembangan dirinya melalui berbagai tahap pendidikan yang menunjang dirinya.

Arti pendidikan menurut Winkel ialah bantuan yang diberikan lingkungan (orang lain, media massa, dan lembaga pendidikan) dalam membantu pendewasaan dan peningkatan pengetahuan. Sedangkan menurut buku Pendidikan Manusia, arti pendidikan harus dapat membuat seseorang menjadi kreatif dalam mengembangkan dirinya. Pendidikan diharapkan dapat lebih menyuburkan kreatifitas dalam diri seseorang sehingga memiliki pengetahuan yang bermanfaat, ditambahkan oleh Emmanuel Kant bahwa pendidikan mempersiapkan seseorang dalam menghadapi kondisi di masa depan bukan hanya sekedar kondisi di saat ini. 
Tujuan pendidikan menurut Unesco membentuk manusia sempurna dalam mengembangkan potensi-potensi individu semaksimal mungkin dalam batas-batas kemampuannya, sehingga terbentuk manusia yang terampil, jujur dan mengetahui kadar-kadar kemampuan serta kehormatan dirinya. Untuk memperoleh pengetahuan yang bermanfaat, setiap manusia harus mau mencari dan memotivasi diri agar memperoleh pengetahuan yang bermanfaat bagi perkembangan kemampuan kognitifnya.

Dalam menyampaikan pesan-pesan yang bersifat pendidikan, peran komunikasi sangat diperlukan. Peran media massa sangat besar dalam menghasilkan efek pada diri seseorang. Seorang komunikator, baik yang bersifat lembaga maupun perorangan memiliki tantangan yang besar dalam menyampaikan informasi pada khalayak luas. Hal tersebut disebabkan karena media massa memiliki efek yang besar. Liliweri berpendapat bahwa media massa memiliki tiga efek, yaitu :

a. Efek Kognitif

Dapat mengakibatkan khalayak berubah dalam pengetahuan, pandangan, dan pendapat terhadap seseuatu yang diperolehnya.

b. Efek Afektif

Efek tersebut mengakibatkan berubahnya perasaan dari khalayak.

c. Efek Konatif

Akibat pesan yang disampaikan mengakibatkan orang mengambil keputusan untuk melakukan atau tidak melakukan sesuatu.

Peran media massa sangatlah besar dalam membentuk pengetahuan pada diri seseorang. Secara terus menerus manusia mencari pengetahuan yang dapat membantu perkembangan dalam dirinya, dan usaha ini merupakan hasil dari efek kognitif.

\section{Film Kartun sebagai Sarana Pendidikan dan Hiburan}

Film kartun yang ditayangkan di televisi sangat dipengaruhi oleh animasi yang terdapat di televisi. Animasi tersebut terbentuk berdasarkan komunikasi visual. Komunikasi visual juga memberikan alat penyampaian pesan bagi khalayak. Dalam 
film dibutuhkan kemampuan menyanpaikan sesuatu secara menarik. Film-film selain diproduksi dan dijual melalui kepingan CD juga ditayangkan melalui televisi. Sebagai suatu saluran hiburan yang palng murah dan mudah diperoleh oleh masyarakat televisi menjadi tontonan missal untuk anak-anak yang tidak memiliki batasan-batasan yang mendidik. Bahkan film kartun dengan alasan sebagai film anak-anak juga yang tidak memiliki batasan yang perlu diedit. Padahal dalam film kartun dapat terselip berbagai pesan yang dapat memberikan pengetahuan pada anak-anak apapun bentuknya.

Berdasarkan hasil riset jumlah penayangan di televisi, meskipun tidak sebanyak sinetron sebuah yayasan di Bandung yaitu Yayasan Pengembangan Media Anak mencatat 41 judul film kartun yang ditayangkan di beragam televisi hingga hari di berbagai jam tayang.

Komunikasi visual merupakan salah satu bentuk komunikasi yang memiliki kekuatan yang besar dalam menyampaikan pesan, hal ini sampaikan Sarah Trendholm dan Arthur Jansen :

1. Komunikasi non verbal seringkali memberikan pesan yang lebih kuat daripada komunikasi verbal.

2. Komunikasi non verbal lebih mengandung kekuatan emosional.

3. Komunikasi non verbal walaupuan dipengaruhi oleh budaya, tetapi dapat mengekspreseikan arti secara universal.

4. Komunikasi non verbal berlangsung sacara terus-menerus dan alami

Bentuk komunikasi non verbal diantaranya termasuk komunikasi visual, yang dalam penyampaian pesannya menggunakan lambing-lambang dan gambar.

Hal ini diperkuat dengan pendapat dari Elizabeth Hurlock dalam buku Psikologi Perkembangan Anak yang mengatakan bahwa media massa memiliki kemampuan untuk mendidik anak-anak melalui pesan yang disampaikan kepada masyarakat. Bahkan keunggula media massa melalui penggunaan gambar-gambar dan lambing, menurut Blair Spencer Ray adalah :

1. Visual dapat mengkondisikan informasi yang besar menjadi relatif kecil.

2. Visual memberikan informasi yang lebih bayak kepada khalayak.

3. Visual mudah dipahami dan dimengerti. 
4. Visual dapat mengekspresikan kondisi secara bersama yang tidak dapat diungkapkan dengan kata-kata.

5. Visual menambah daya tarik dan lebih menghidupkan komunikasi verbal dan non verbal..

Lebih ditekankan oleh Elizabeth Hurlock fungsi media massa bergambar yang menarik membuat anak-anak memperoleh informasi mengenai orang, benda, dan situasi yang sebelumnya tidak dimengerti. Pengamatan ini akan membuat daya pikir anak menjadi meningkat dan akan mempengaruhi frame of reference dan field of experience.

Kelebihan media gambar juga diungkapkan oleh Dr. Arief Sadiman, M.Sc dalam buku Media Pendidikan adalah :

1. Sifatnya konkrit, gambar atau foto lebih realistis menunjukkan pokok masalah dibandingkan benda yang digambarkan secara verbal.

2. Gambar tidak dibatas oleh ruang dan waktu

3. Media gambar dapat lebih jelas mendeskripsikan tentang sesuatu hal yang menarik pada anak-anak.

\section{Pendidikan Moral dalam Film Kartun Anak-Anak di Televisi Indonesia}

Perilaku moral berarti perilaku yang sesuai dengan kode moral kelompok sosial. Moral berasal dari kata latin mores yang berarti tatacara, kebiasaan, dan adat. Perilaku moral dikendalikan konsep-konsep moral peraturan perilaku yang telah menjadi kebiasaan bagi anggota suatu budaya dan yang menentukan pola perilaku yang telah menjadi kebiasaan bagi anggota suatu budaya dan yang menentukan pola perilaku yang diharapkan dari seluruh anggota kelompok (Hurlock, 1999 : 74). Sedangkan menurut Hurlock, perilaku tak bermoral ialah perilakuyang tidak sesuai dengan harapan sosial. Perilaku demikian tidak disebabkan ketidakacuhan akan harapan sosial melainkan ketidaksetujuan dengan standar sosial atau kurang adanya perasaan wajib menyesuaikan diri.

Perkembangan moral mempunyai aspek kecerdasan dan aspek impulsive. Anak harus belajar apa saja yang benar dan mengetahui apa saja yang salah. Proses pembelajaran moral merupakan hal yang perlu diperhatikan bagi seorang anak 
untuk bertahan dalam menghadapi kehidupannya. Dengan pemahaman moral yang baik akan membuat anak menjadi lebih memahami dirinya dan kepentingan dari orang lain yang akan memberikan manfaat bagi kebutuhan dirinya tersebut.

Dalam penelitian ini, film-film kartun anak-anak yang diteliti terdapat di RCTI, MNC TV dan SpacetoonTV.

\section{Film Kartun Di RCTI}

\section{Film Winnie The Pooh}

Adalah film yang berbau pendidikan dan memberikan pelatihan yang berguna bagi anak-anak yang masih membutuhkan bimbingan. Sifat periang dan rasa ingin tahu sangat diutamakan dalam film ini. Film Winnie the pooh sangat mengutamakan kebersamaan dan rasa saling memiliki sebagai sahabat sehingga mereka saling tolong menolong dan saling membantu satu sama lain. Rasa persaudaraan dan tanggung jawab satu dengan yang lain membuat suasana menjadi lucu, humoris dan mengharukan. Setiap adegan yang ditampilan menunjukkan kepribadiaan tiap pemain dalam film ini.

\section{Film Shinchan}

Adalah film kartun anak-anak kategory porno dan hanya bersifat hiburan karena dalam film ini sinchan mempunyai karakter yang jahil dan terkadang terlihat melecehkan wanita. Film ini seharusnya tidak di tonton oleh anak-anak karena film ini kategori orang dewasa, jadi jika anak-anak ingin menonton film ini harap didampigi oleh orang tuanya. Kategori film yang dapat disaksikan oleh anak-anak adalah film yang baik yang menjunjung tinggi norma kesopan santunan dan terdapat pendidikan didalamnya agar anak -anak dapat menghibur diri sekaligus belajar dari film tersebut.

\section{Film Doraemon}

Adalah Film kartu anak pendidikan dan juga film kartun anak-anak tentang kekerasan. Dalam kartun ini mengulas kisah nobita yang selalu manja dan tidak mau usaha maka dia selalu mengandalkan doraemon dengan meminta doraemon untuk mengeluarkan alat-alat canggih yang digunakan untuk membantu 
menyelesaikan tugas-tugasnya,tapi dia selalu kena batunya karena menyalahgunakan alat-alat doraemon tersebut.

\section{Pesan Moral}

\section{Film Winnie The Pooh}

Makna yang bisa dipetik dari film yang bergurasi tidak lebih dari satu jam ini memberikan banyak pesan-pesan pendidikan yang mendidik antara lain :

- $\quad$ Saling tolong menolong

- Ikhlas dalam membantu setiap orang

- $\quad$ Berusaha dengan sepenuh hati dalam membantu orang lain

- Pengorbanan

- $\quad$ Saling pengertian

- $\quad$ Saling menghargai

- $\quad$ Penghargaan atau Ucapan terima kasih

- $\quad$ Saling memberi

- $\quad$ Saling menerima perbedaan

- $\quad$ Saling menghibur

- $\quad$ Saling memberikan semangat dan masukan

- $\quad$ Membangun tali persaudaraan dengan saling menolong

- Tidak merugikan orang lain.

- $\quad$ Semangat

- $\quad$ Cinta Kasih

- Persaudaraan

- $\quad$ Tidak memberikan dukungan

- $\quad$ Tidak pandang bulu

- $\quad$ Saling mengasihi

- $\quad$ Saling percaya

- $\quad$ Saling menghibur dikala susah maupun senang

- $\quad$ Dan masih banyak nilai moral lain yang dapat dipetik lainnya. 


\section{Film Shinchan}

Pesan moral dan Film ini adalah dalam bergaul sebaiknya kita menjunjung tinggi sopan santun dan jangan seperti sinchan yang hanya bersikap semaunya tanpa ada sopan santun ketika dia sedang bergaul dan berhadapan dengan orang yang lebih dewasa.Pesan moral bersifat etiket dalam pergaulan. Dalam bergaul sebaiknya kita mempunyai sopan santun yang dapat menjadi cerminan dari pribadi kita, dan kita juga harus menghargai dan menghormati orang yang lebih tua dari kita.

\section{Film Doraemon}

Pesan-pesan moral yang terkandung dalam film doraemon: Jangan selalu bergantung pada siapun, lebih baik kita berusaha sendiri dengan keras untuk mencapai tunjuan yang kita inginkan. Banyak nilai nilai moral yang terkandung dalam film ini.Karena itu mengaitkan meteri pelajaran dengan pesan moral yang terkandung dalam film ini. Dapat merangsang anak untuk semangat belajar. Pesan moral terdapat dalam film ini adalah etiket dalam pergaulan. Nobita sering memencing perhatian teman-temannya dengan mengeluarkan alat-alat canggih milik doraemon,seharusnya dalam bergaul kita harus tulus dalam membantu teman-teman kita dengan begitu teman-teman kita juga dapat dengan tulus untuk berteman dengan kita.

\section{Film Kartun di MNC TV}

\section{Disney Club}

Para tokoh Disney Club yang terkenal dengan karakternya yang unik juga ikut menyemarakkan tayangan-tayangan istimewa TPI. Yang pertama tentu saja Mickey Mouse. Seekor tikus yang ceria, multi talent, lucu, baik, suka menolong, easy going dan menyenangkan. Tak heran jika Minnie yang manis dan manja mau menjadi kekasihnya.

Mickey memiliki teman yakni Donald Duck, seekor bebek yang mengenakan pakaian pelaut berwarna biru, yang memiliki kekasih hati bernama Daisy Duck. Yang tak kalah lucu adalah tingkah dari 3 keponakan Donald, yaitu Huey, Devvey, Louie yang jahil dan menggemaskan, serta 2 rupai yang suka menggoda dan memancing kemarahan Donald, yakni Chip Dale.Satu lagi teman Mickey dan Donald adalah 
Goofy Goofy dikenal sebagai anjing yang bodoh dan setia, namun memiliki kekuatan ekstra. Aksi-aksi seru dan menghibur Mickey Mouse, Donald Duck, Pluto, Goofy dkk ini hadir Senin-Jumat pukul 07.30 WIB, Senin-Sabtu pukul 15.30 WIB dan Minggu pukul 14.30 WIB.

\section{Little Khrisna}

Khrisna di masa kecil. Khrisna bagi masyarakat India adalah sosok yang didewakan. Tokoh dari cerita Mahabharata ini adalah titisan dewa Wishnu di dunia. Karena muncul di cerita Mahabharata, yang jadi sumber cerita pewayangan, kita pun akrab dengan sosok Khrisna.masa kecil Khrisna yang tinggal bersama dua orangtuanya, Nanda dan Yashoda dan kakaknya, Balram di desa Vrindavan.

Khrisna bukan anak sembarangan. Ia punya kekuatan magis layaknya superhero. Meski begitu, ia tetaplah anak-anak. Ia jahil dan nakal. Bersama gangnya, Madhumagal, Subala, Radha, Hamsi si lembu kecil, dan Dadiloba si kera. Hobi mereka, mencuri mentega dan susu.

Khrisna yang jahil tapi sakti jadi incaran Kamsa, sang raja lalim. Meski Khrisna masih kecil, Kamsa menganggapnya sebagai musuh utama. Sebab, di masa lalu Kamsa pernah diramal kalau singgasananya akan runtuh, dan seorang penyelamat akan muncul di bumi untuk membinasakannya. Kamsa yakin sang penyelamat dimaksud adalah Khrisna. Maka, Kamsa tak henti mengirim monster jahat ke Vrindavan untuk membunuh Khrisna. Kisahnya tak sekadar tentang kenakalan anak-anak semata, tapi juga ada adegan pertempuran fantastik yang memanjakan mata.

\section{Bernard Bear}

Dia adalah beruang kutub. Tentu saja berwarna putih. Bertampang lucu tapi terlihat bodoh. Sering membuat masalah dan acapkali mendapat kesialan. Dialah Bernard si beruang alias Bernard Bear. Bernard Bear adalah rangkaian animasi pendek animasi seekor beruang kutub sebagai tokoh utama dengan nama yang sama. Ini adalah Animasi Produksi bersama oleh Korea, Perancis dan Spanyol..

Bernard tidak pernah berbicara dengan pengecualian suara yang mudah untuk dipahami. Film Bernard Bear bisa dibilang cukup sederhana sebab hanya ada lima tokoh utama yaitu seekor beruang kutub, kadal, seekor anjing Chihuahua dan dua 
pinguin. Selain empat tokoh tersebut bisa dibilang hanya figuran. Sering kali Bernard Bear tampil sendiri tanpa teman-temannya tapi tetap lucu. Dia biasanya mendapatkan sadarkan diri pada akhir episode, karena beberapa bencana yang disebabkan oleh ulahnya sendiri.

\section{Upin Ipin}

Film kartun upin dan ipin merupakan film dari negara Malaysia, mengisahkan tentang sepasang anak kembar laki - laki yang bernama Upin dan Ipin yang tinggal bersama kakaknya "Kak Ros" dan neneknya "Opa". Dalam film animasi ini, tidak hanya memunculkan etnik-etnik yang ada di Malaysia tetapi juga ada Etnik Melayu, China maupun India. Settingnya sendiri akan membawa kita berada ditengah pedesaan yang syarat dengan silaturahmi beragama. Peleburan Kultur yang beragam tanpa ada jarak sangat kental terasa. Meskipun film kartun ini berdialek Melayu, tapi kita orang Indonesia masih dapat dengan mudah menyerap maksud dan tujuannya.

\section{Pesan Moral}

\section{Disney Club}

Sebaiknya kita sebagai warga negara Indonesia yang baik tidak boleh menebang pohon sembarangan. Terlihat dalam film kartun Disney Club yamg mengajarkan kepada kita bahwa penebangan tanpa izin merupakan hal terlarang, karena dapat merugikan lingkungan sekitar termasuk hewan-hewan yang berada di lingkungan sekitar.Dapat kami simpulkan bahwa pesan moral yang terlampir adalah pesan moral yang bersifat sopan santun etiket.

\section{Little Khrisna}

Kita tidak boleh membalas kejahatan dengan kejahatan justru sebaliknya kejahtan harus di balas dengan kebaikan. Film ini dapat dikonsumsi sama anak-anak karena mereka dapat mengikuti karakter seperti Krishna yang berani melawan kejahatan.

\section{Bernard Bear}

Bagi peneliti jalinan cerita pada kartun Bernard lebih mudah dipahami daripada kisah sinetron. Padahal sinetron lebih banyak berbicara, tapi tetap saja alur ceritanya tidak jelas. Bernard dan kawan-kawannya, Llyod dan Eva si penguin, Zack si kadal 
lebih bisa menyampaikan pesan dengan tanpa bersuara. Sebaliknya, kebanyakan cerita sinetron tak jelas apa pesan yang disampaikan dengan dialog-dialognya yang bombastis. Meskipun kartun ini bisu alias tidak ada suara dubbing, tapi tetap saja menarik dan lucu. Pesan yang disampaikan mudah ditangkap.

Film kartun ini dapat ditonton untuk semua kalangan, tidak hanya untuk anak kecil saja, tapi orangtua pun juga dapat menonton film ini dan dapat terhibur juga karena tingkah laku dari setiap tokoh tersebut. Film ini mengajarkan anak-anak untuk dapat berfikir cerdik dan dapat saling bekerja sama satu dengan yang lain. Tetapi bagi yang menonton film ini, jangan mengikuti tingkah laku Bernard yang ceroboh, konyol dan bodoh.

\section{Upin Ipin}

Film kartun Upin dan Ipin ini merupakan jenis kartun anak-anak yang yang bertemakan tentang keagamaan dan pendidikan. Hal ini didasarkan pada jalan cerita yang ditampilkan dalam cerita kartun tersebut dimana mengajarkan anakanak mengenai caranya berpuasa terutama untuk anak-anak yang baru menjalani tradisi berpuasa. Dimana mereka banyak menggunakan waktunya untuk melakukan aktivitas-aktivitas yang mengajarkan mereka tentang sesuatu yang baru dan memberikan pelajaran yang positif dan baru bagi anak-anak khususnya anakanak yang berusia 4-6 tahun, contohnya bermain badminton atau bermain kelereng. Dari hal tersebut, ada banyak pesan moral yang disampaikan cerita kartun tersebut untuk anak-anak, tidak terkecuali bagi anak-anak di Indonesia yang beragama muslim. Selain diajarkan mengenai bagaimana caranya untuk berpuasa yang baik bagi kaum awam yang baru saja melakukan puasa serta bagaimana menggunakan waktu dengan baik selama menunggu waktu untuk berpuka puasa. Selain itu, diajarkan juga mengenai bagaimana cara untuk menghormati orang yang lebih tua supaya selalu mendengarkan setiap perkataan yang diberitahukan. Disamping hal tersebut, lewat kartun upin-ipin, anak-anak Indonesia juga diajarkan mengenai kebudayaan dari Malaysia sehingga mereka bisa mengenalinya bahkan tidak jarang saat ini banyak anak Indonesia yang mengikut dialeg dari upin-ipin dalam percakapan sehari-hari mereka. 
Cerita kartun ini merupakan salah satu cerita anak-anak yang dapat menjadi contoh bagi para animator Indonesia untuk membuat suatu kemasan cerita kartun yang unik mengenai kehidupan sehari-hari dengan menyuguhkan kebudayaan bangsa Indonesia yang beragam sehingga para kaum muda terutama anak-anak dapat mengetahui kebudayaan Indonesia yang beraneka ragam dan unik. Namun dilengkapi dengan unsur pendidikan tanpa menampilkan unsur kekerasan, karena pada dasarnya anak-anak masih belum tahu dan belum mengerti mengenai apa yang boleh ditiru dan apa yang tidak boleh untuk ditiru. Sehingga kalangan muda yang merupakan masa depan dari suatu Negara dapat meningkatkan rasa Nasionalisme dan didukung dari segi pendidikan dan teknologi yang semakin lama semakin berkembang dan maju.

\section{Spacetoon TV}

\section{The Magic School Bus - Science}

Bercerita tentang bis sekolah ajaib yang dikendarai oleh miss frizzle bersama muris-muridnya. Miss frizzle adalah seorang guru sains yang sering mengajak murid-muridnya pergi berpetualang di dunia saind, supaya mereka bisa memahami pelajaran sains yang mereka pelajari dikelas. Magic School bus bisa berubah bentuk, warna dan ukuran, juga bisa membawa mereka kemana-mana. Bahkan mereka bisa menjadi sesuatu yang tudak mereka fikirkan . misalnya , menjadi bensin , kayu , pensil dll . disitu juga ada kadal ajib yang bernama Lizzy.

\section{Asari Chan}

Ayah Asari adalah seorang eksekutif dari perusahaan besar, ibu lulus dari universitas elit, dan kakaknya sangat cerdas. Namun, Asari-chan adalah seorang gadis yang cukup 'luar biasa' kelakuannya. Oleh karena itu, Asari-chan selalu diejek oleh adiknya, dan ibunya tegur dia untuk nilai-nilai buruk nya. Tapi, dia hidup dengan riang tidak tertekan.

\section{Tiny Planets}

Helly mengundang Bing dan Bong untuk berpetualang di Tiny Planets yang sangat seru dan banyak menemukan hal-hal baru. Petualangan ini diawali dengan kepergian Bing dan Bong ke planet kecil. Di sini ada mesin yang dapat mengubah 
musim berganti dengan cepat, dari musim panas, semi, gugur, dan dingin dengan hanya menekan sebuah tombol. Ajaib yaa.

\section{Pesan Moral}

\section{The Magic School Bus - Science}

Film ini menceritkan mengenai tentang pelajaran IPA yang dijelaskan secara menarik oleh miss frizzle, dia membawa anak-anak muridnya unutk belajar di luar, agar para siswa mampu menangkap pelajaran dengan lebih mudah dan mereka dapa mengetahui dengan jauh lebih baik , apa itu IPA sebenarnya . Karena semakin sering kita belajar dan mencari tahu tentang sesuatu, semakin banyaklah pengetahuan yang kita ketahui .

\section{Asari Chan}

Asari memang di gambarkan sedikit nakal dalam kartun ini namun sikap yang dapat kita petik dari kartun ini adalah sikap pantang menyeRah asari dalam mencapai keinginannya. Selalu berusaha keras untuk apa yang dia inginkan.

\section{Tiny Planets}

Kartun ini mengajarkan untuk banyak berkreasi, bagaimana kita memperlajari suatu kondisi yang ada dan mencari solusi yang tepat bagi semua pihak yang bersangkutan. Bing dan bong mengajarkan persahabatan yang selalu ada dalam menghadapi suatu masalah yang ada bersama-sama saling membantu satu sama lain.

\section{Penutup}

Berdasarkan hasil penelitin yang dilakukan oleh peneliti, maka peneliti menyampaikan bahwa hiburan film-film kartun yang ada di televisi nasional masih sedikit yang memberikan pesan moral. Pesan moral banyak tertutup dengan adegan kekerasan dan horor. Penelitian ini melihat bahwa anak-anak hanya sekedar memperoleh hiburan semata tanpa memperoleh hal yang bermanfaat bagi pengembangan pengetahuan dan motoriknya. Banyak manfaat yang kurang baik bagi anak-anak apabila mereka kemudian mengeluarkan kata-kata tidak sopan, 
kasar, dan tidak sesuai dengan usianya. Bahkan tidak hanya kata-kata yang dikeluarkan tetapi disertai aksi kekerasan yang ditiru dari film kartun yang ada di televisi.

Hal menarik, peneliti melihat pesan-pesan moral yang ditampilkan juga belum ada dalam film-film kartun yang ditayangkan di televisi nasional memiliki nilai-nilai sesuai budaya Indonesia, selain karena kualitas film kartun asing yang masih kurang baik. Tetapi secara moral tetapi juga dipengaruhi budaya barat, Malaysia, India, China, dan Jepang yang tidak sesuai dengan kebudayaan anak-anak Indonesia.

\section{DAFTAR PUSTAKA}

De Vito, Joseph(2000). The Interpersonal Communication Book. USA: Donneley\&Sons Company

Effendy, Onong Uchjana (2000). Pengantar Ilmu Komunikasi. Bandung : PT Rosdakarya

Siregar,Ashadi (2006). Etika Komunikasi. Yogyakarta : Pustaka Book

Postman, Neil(1995). Menghibur Diri Sampai Mati Mewaspadai Media Televisi. Jakarta : Pustaka Sinar Harapan

Littlejohn, Stephen W (2009). Theories of Human Communication. London :Wadswoth

Mahayoni (2008), Anak vs Media. Jakarta : PT Elex Media Komputindo

Mulyana, Deddy (2008). Pengantar Ilmu Komunikasi, Bandung : PT Rosdakarya

Sim, Stuart(2008). Memahami Teori Kritis, Yogyakarta : Resist Book

Tondowidjodjo (1985). Media Massa dan Pendidikan, Yogyakarta : Kanisius

Yusup, Pawit (1990). Komunikasi Pendidikan dan Komunikasi Instruksional. Bandung : Remaja Rosdakarya

Wilkins(2009), Mass Media Ethics, London : Prentince Hall 